\title{
PENGARUH PROPORSI DAMI NANGKA TERHADAP KARAKTERISTIK KIMIA, FISIK DAN ORGANOLEPTIK SELAI LEMBARAN NANAS
}

\author{
[The Effect of Straw Jackfruit Proportion on the Chemical, Physical and Organoleptic \\ Characteristics of Pineapple Slice Jam]
}

\author{
Ni Made Neni Parmiutari*, Eko Basuki, dan Rucitra Widyasari \\ Program Studi Ilmu dan Teknologi Pangan, Fakultas Teknologi Pangan dan Agroindustri, \\ Universitas Mataram \\ *Email: neniparmiutari@gmail.com
}

Diterima 14 Oktober 2020 / Disetujui 28 Desember 2020

\begin{abstract}
This study aims to determine the chemical properties (moisture content, $\mathrm{pH}$ and total dissolved solid), physical properties (texture and color) and organoleptics (taste, color, aroma, texture) in the different formulation of slice jam from mixture straw jackfruit and pineapple. This study used a Completely Randomized Design (CRD) with 6 treatments and 3 time replications and analyzed using Analysis of Variance at the $5 \%$ level and followed by Least Significant Difference test at the 5\% level. These treatments include PO (100\% pineapple), P1 (80\% pineapple: 20\% straw jackfruit), P2 (65\% pineapple: 35\% straw jackfruit), P3 (50\% pineapple: $50 \%$ straw jackfruit), P4 (35\% pineapple: 65\% straw jackfruit), dan P5 (20\% pineapple: $80 \%$ straw jackfruit). Observations made on moisture content, $\mathrm{pH}$, total dissolved solid, texture, color and organoleptic taste, color, texture and aroma (scoring and hedonic). The results showed that the P3 treatment (50\% straw jackfruit: $50 \%$ pineapple) was the preferred treatment for the panelists on the parameters of color, taste, and texture with the characteristics of moisture content 23.35\%, pH 4.86, total dissolved solids 32,46 Brix, L value 44.79 and Hue value 70.670 and brownish yellow color, slightly pineapple taste, chewy texture and pineapple aroma and slightly jackfruit aroma.
\end{abstract}

Keywords: pineapple, slice jam, straw jackfruit

\section{ABSTRAK}

Penelitian ini bertujuan untuk mengetahui sifat kimia (kadar air, pH dan total padatan terlarut), sifat fisik (tekstur dan warna) dan organoleptik (rasa, warna, aroma, tekstur) pada formulasi selai lembaran dari campuran dami nangka dan buah nanas yang berbeda. Penelitian ini menggunakan Rancangan Acak Lengkap (RAL) dengan 6 perlakuan dan 3 kali ulangan dan dianalisis menggunakan analisis keragaman (Analysis of Variance) pada taraf $5 \%$ dan dilanjutkan dengan uji Beda Nyata Terkecil pada taraf 5\%. Perlakuan diantaranya P0 (100\% buah nanas), P1 (80\% buah nanas: $20 \%$ dami nangka), P2 (65\% buah nanas: $35 \%$ dami nangka), P3 (50\% buah nanas: 50\% dami nangka), P4 (35\% buah nanas: $65 \%$ dami nangka), dan P5 ( $20 \%$ buah nanas: $80 \%$ dami nangka). Pengamatan dilakukan terhadap kadar air, $\mathrm{pH}$, total padatan terlarut, tekstur, warna dan organoleptik rasa, warna, tekstur dan aroma (skoring dan hedonik). Hasil penelitian menunjukkan bahwa perlakuan P3 (50\% dami nangka : 50\% buah nanas) merupakan perlakuan yang agak disukai panelis pada parameter warna, rasa, dan tekstur dengan karakteristik kadar air 23,35\%, pH 4,86, total padatan terlarut $32,46^{\circ}$ Brix, nilai $\mathrm{L} 44,79$ dan nilai Hue $70,67^{\circ}$ serta warna kuning kecokelatan, agak berasa asam nanas, tekstur kenyal dan beraroma nanas dan sedikit beraroma nangka.

Kata kunci: buah nanas, dami nangka, selai lembaran

\section{PENDAHULUAN}

Tanaman nangka merupakan tanaman yang banyak ditemukan di daerah tropis, seperti Indonesia. Tanaman nangka dapat berbuah sepanjang tahun dan bukan merupakan buah musiman. Buah nangka terdiri dari daging buah, biji dan dami atau jerami. Semua bagian dari nangka memiliki banyak manfaat yang dapat diambil. Buah nangka sangat digemari di Indonesia karena rasanya yang manis sedangkan dami atau jerami nangka masih kurang dimanfaatkan karena masih dianggap sebagai limbah (Widyastuti, 1993 dalam Rayl, 2018). 
Versi Online:

http://www.profood.unram.ac.id/index.php/profood e-ISSN: 2443-3446

Dami atau jerami nangka adalah bunga yang tidak mengalami penyerbukan yang berada diantara daging buah nangka. Nangka yang masih muda seluruh bagiannya yaitu daging buah, biji dan dami dapat dimanfaatkan secara bersamaan. Sedangkan saat matang dami nangka tersebut dibuang karena rasanya yang tidak manis (Handayani, 2016). Dami nangka mengandung serat serta pektin yang merupakan salah satu syarat dalam pembuatan selai lembaran. Kandungan karbohidrat total pada dami nangka yang terdiri dari glukosa, fruktosa, sukrosa, pati, serat dan pektin mencapai $15,87 \%$ dengan $1,94 \%$ merupakan serat kasar dan 2,38\% adalah pektin (Siregar, 1996 dalam Handayani, 2016).

Mengingat jumlah dami nangka yaitu sekitar $40-50 \%$ dari limbah nangka yang dihasilkan maka dengan proses pengolahan yang tepat seperti menjadi selai lembaran maka diharapkan depat meningkatkan nilai jual dari hasil samping buah nangka (Yusmita dan Wijayanti, 2018). Salah satu syarat dalam pengolahan selai lembaran yaitu buah yang digunakan harus mengandung pektin. Dami nangka mengandung pektin yang cukup untuk membuat selai yaitu $2,38 \%$ sedangkan untuk membentuk gel pada kondisi optimum dibutuhkan kadar pektin 0,75-1,5\% (Muchtadi, 1997 dalam Ramadhan, 2011). Namun, dalam pengolahannya dami nangka memiliki kekurangan yaitu tidak memiliki rasa yang khas karena dami nangka tidak mengandung asam yang dapat menciptakan citarasa, sehingga untuk menutupi kekurangan dari selai lembaran dami nangka maka diperlukan penambahan buah yang juga dapat meningkatkan keasaman dari selai lembaran sehingga konsistensi gel yang diinginkan dapat tercapai. Salah satu buah yang dapat ditambahan pada selai adalah buah nanas.

Pemilihan buah nanas sebagai bahan substitusi dalam pembuatan selai lembaran ini dimaksudkan selain agar selai yang dihasilkan memiliki citarasa yang segar yang dapat diterima oleh konsumen juga kandungan vitamin C yang tinggi $(20 \mathrm{mg} / 100 \mathrm{gram})$ buah nanas diharapkan mampu menutupi kekurangan dari dami nangka (Direktorat Gizi Depkes Ri, 1998).

Selai merupakan salah satu produk pangan yang bersifat semi basah dengan memasak buah yang telah menjadi bubur yang dicampur dengan gula. Sementara itu selai lembaran adalah bentuk praktis dari selai oles yang dimodifikasi sehingga bersifat kompak, plastis dan tidak lengket. Bahan utama selai adalah buah yang mengandung pektin yang cukup untuk menghasilkan tekstur yang baik. Pektin adalah senyawa karbohidrat yang dapat membentuk gel jika bereaksi dengan gula dan asam. Menurut Iswara (2017), proses pembuatan selai lembaran hampir sama sengan proses pembuatan selai oles, namun pada selai lembaran dilakukan pencetakan selai menjadi lembaran dengan ketebalan 2-3mm.

Dalam pembuatan selai terdapat beberapa faktor yang harus diperjatikan antara lain pengaruh panas dan gula selama pemasakan, serta keseimbangan proporsi gula, pektin dan asam (Ramadhan, 2011). Formulasi sukrosa, asam sitrat dan agar-agar tepung terbaik berdasarkan penelitian Ramadhan dan Trilaksani (2017) pada pembuatan selai lembaran adalah gula $90 \%$, asam sitrat 0,04\% dan agar-agar tepung $0,9 \%$. Penambahan asam bertujuan mengatur $\mathrm{pH}$ dan menghindari pengkrsitalan gula. Asam yang biasa digunakan dalam pembuatan selai adalah asam sitrat, asam tartat, dan asam malat. Penggunaan asam tidak mutlak tetapi penambahannya dilakukan untuk menambah cita rasa dari produk makanan. Apabila terlalu asam akan terjadi sineresis yakni keluarnya air dari gel sehingga kekentalan selai akan berkurang bahkan tidak terbentuk gel sama sekali (Fachrudin, 2008 dalam Ramadhan, 2011). Penambahan gula juga berpengaruh pada kekentalan atau osmolalitas dan kekuatan gel yang terbentuk. Proses pemasakan selai dengan konsentrasi gula yang tinggi akan meningkatkan viskoitas gel (Maceiras, dkk 2007 dalam Ramadhan, 2017).

Berdasarkan hasil penelitian Tarmizi (2011), menyatakan bahwa perbandingan jumlah daging buah nangka dan dami nangka yang terbaik adalah 35\% daging buah : $65 \%$ dami 
Versi Online:

http://www.profood.unram.ac.id/index.php/profood e-ISSN: 2443-3446

nangka dengan kadar air 19,9\%, kadar pektin $0,86 \%$, kadar gula 76,065 , total asam $0,72 \%$, dan kadar serat kasar 1,23\%. Penelitian mengenai pembuatan selai lembaran berbahan dasar dami nangka dan buah nanas belum pernah dilakukan, namun selai lembaran berbahan dasar dami nangka pernah ditambahkan dengan daging buah nangka. Berdasarkan hal tersebut, maka dilakukan penelitian mengenai pengaruh proporsi dami nangka terhadap karakteristik kimia, fisik dan organoleptik selai lembaran nanas.

\section{BAHAN DAN METODOLOGI}

\section{Bahan}

Bahan yang digunakan dalam penelitian ini adalah dami nangka dari nangka salak yang diperoleh dari Desa Sandik kecamatan Batu Layar kabupaten Lombok Barat, buah nanas madu, gula pasir, asam sitrat, air, margarin, tepung agar-agar (Swallow), aquades.

Alat-alat yang digunakan dalam penelitian ini meliputi baskom, blender, timbangan analitik (Kern), pengaduk, sendok, kompor, panci, kantong plastik, pengiling, pisau, loyang, pH meter (Schott), botol UC, gelas piala $5 \mathrm{ml}$, gelas ukur $5 \mathrm{ml}$, oven, cawan, hotplate (IEC), magnetic stirer, colorimeter (MiniScan EZ), refraktometer dan penetrometer.

\section{Metode}

Metode yang digunakan dalam penelitian ini adalah metode eksperimental yang dilaksanakan di laboratorium.

\section{Pelaksanaan penelitian:}

\section{Pembuatan Bubur Dami Nangka}

1. Pencucian

Pencucian

menggunakan air mengalir. Pencucian bertujuan untuk menghilangkan kotoran yang ada pada dami.

\section{Pemotongan}

Pemotongan bertujuan untuk memperkecil ukuran dami nangka dan memperbesar luas permukaan dami sehingga dami nangka lebih mudah dihancurkan.

3. Blansing

Blansing bertujuan untuk melunakkan jaringan, memperbaiki tekstur dan mengurangi kontaminasi. selain itu, pengukusan juga dapat mengurangi getah yang terdapat pada dami nangka dan menurunkan pencoklatan. Blansing dilakukan dengan metode uap pada suhu $100^{\circ} \mathrm{C}$ selama 15 menit.

4. Penghancuran

Penghancuran bertujuan untuk mendapatkan bubur dami nangka. Penghancuran dilakukan dengan penambahan air dengan perbandingan $1: 1$.

\section{Pembuatan Bubur Buah Nanas}

\section{Pengupasan}

Pengupasan bertujuan untuk memisahkan daging buah nanas dengan kulitnya.

\section{Pencucian}

Pencucian dilakukan dengan menggunakan air mengalir. Pencucian bertujuan untuk menghilangkan kotoran yang ada pada buah nanas.

3. Pemotongan

Pemotongan bertujuan untuk memperkecil ukuran buah nanas dan memperbesar luas permukaan nanas sehingga dami nangka lebih mudah dihancurkan.

4. Penghancuran

Penghancuran bertujuan untuk mendapatkan bubur nanas. Penghancuran dilakukan tanpa menambahkan air.

\section{Pembuatan Selai Lembaran}

1. Pencampuran

Bubur dami nangka dan buah nanas dicampur dengan asam sitrat sebanyak 0,08 g.

2. Pemasakan I

Campuran bubur dami nangka dan buah nanas dipanaskan dan dibiarkan hingga mendidih selama 5 menit.

3. Pemasakan II

Campuran bubur dami nangka dan buah nanas kemudian ditambahkan tepung agar $1,8 \mathrm{~g}$, gula $100 \mathrm{~g}$ dan margarin $2 \mathrm{~g}$. Pemasakan dilakukan selama 20 menit dengan api sedang.

4. Pencetakan 
Versi Online:

http://www.profood.unram.ac.id/index.php/profood e-ISSN: 2443-3446

Selai yang telah masak dicetak dalam loyang untuk menghasilkan selai dalam bentuk lembaran. Pencetakan dilakukan dengan meratakan seluruh selai ke permukaan loyang dan dibiarkan hingga dingin.

5. Pendinginan

Pendinginan bertujuan untuk menurunkan suhu selai lembaran.

6. Pemotongan

Selai yang telah dingin kemudian dipotong dengan ukuran $8,5 \times 8,5 \mathrm{~cm}$.

\section{Rancangan Percobaan dan Analisis Data}

Rancangan yang digunakan pada penelitian ini adalah Rancangan Acak Lengkap (RAL) dengan dengan 5 perlakuan dan 1 kontrol dengan 3 kali ulangan.

$\mathrm{PO}=100 \%$ buah nanas

$\mathrm{P} 1=80 \%$ buah nanas: $20 \%$ dami nangka

$\mathrm{P} 2=65 \%$ buah nanas: $35 \%$ dami nangka

P3 $=50 \%$ buah nanas: $50 \%$ dami nangka

$\mathrm{P} 4=35 \%$ buah nanas: $65 \%$ dami nangka

P5 $=20 \%$ buah nanas: $80 \%$ dami nangka

Data pengamatan analisa sifat fisik dan kimia kadar air (metode termogravimetri) (Widianto, 2009) serta penilaian organoleptik dianalisis menggunakan analisis Sidik Ragam atau ANOVA (Analysis of Variance) pada taraf nyata $5 \%$ menggunakan software Co-stat. Apabila terdapat perbadaan nyata pada paramater uji, maka dilanjutkan dengan uji Beda Nyata Terkecil (BNT) pada taraf 5\%.

\section{HASIL DAN PEMBAHASAN}

\section{Kadar Air}

Perbandingan jumlah dami nangka dan buah nanas yang berbeda memberikan pengaruh yang berbeda nyata terhadap kadar air selai lembaran. Hubungan antara perbandingan jumlah dami nangka dan buah nanas dengan kadar air selai lembaran yang dihasilkan dapat dilihat pada Gambar 1.

Berdasarkan Gambar 1 menunjukkan bahwa perbandingan jumlah dami nangka dan buah nanas yang berbeda berpengaruh berbeda nyata terhadap kadar air selai lembaran rata-rata kadar air selai pedada berkisar antara 21,28\%-24,66\%. Kadar air tertinggi dimiliki oleh perlakuan P4 (35\% buah nanas : $65 \%$ dami nangka) yaitu $24,66 \%$ dan terendah dimiliki oleh perlakuan PO (100\% buah nanas).

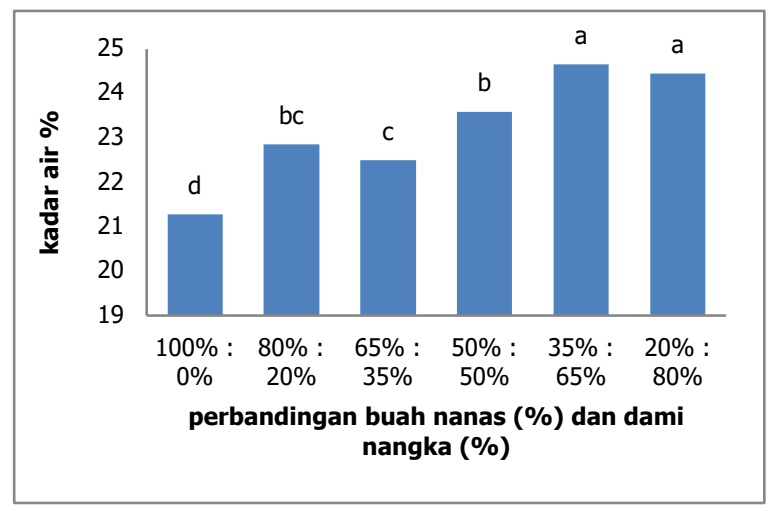

Gambar 1. Pengaruh Perbandingan Jumlah Dami Nangka dan Buah Nanas yang Berbeda Terhadap Kadar Air Selai Lembar

Peningkatan kadar air selai lembaran cenderung meningkat seiring dengan penambahan jumlah dami nangka dan menurunnya jumlah buah nanas. Peningkatan kadar air selai lembaran diduga sebagai akibat dari penambahan air pada dami nangka saat penghancuran. Dami nangka ditambahkan air sebanyak 1 liter untuk $1 \mathrm{~kg}$ dami nangka agar memudahkan dan mempercepat proses penghancuran karena dami nangka memiliki tekstur yang agak alot. Hasil penelitian ini tidak sesuai dengan hasil penelitian oleh Wahyuni dkk (2017) mengenai pembuatan selai campuran dami nangka dan buah sirsak. Pada penelitian tersebut kadar air yang dihasilkan cenderung meningkat dengan seiring menurunnya jumlah bubur dami nangka yang ditambahkan. Hal tersebut diduga akibat dari perbedaan proses pembuatan selai, dimana pada saat penghancuran buah sirsak ditambahkan air dengan perbandingan $1: 1$, sedangkan pada penelitian ini pada saat penghancuran buah nanas tidak ditambahkan air. Berdasarkan SNI 01-3746-2008 tahun 2008, kadar air maksimum untuk selai adalah $35 \%$ sehingga semua perlakuan pada penelitian ini memenuhi standar kadar air selai tersebut.

\section{Derajat Keasaman (pH)}


Perbandingan jumlah dami nangka dan buah nanas memberikan pengaruh yang berbeda nyata terhadap nilai $\mathrm{pH}$ selai lembaran. Hubungan perbedaan jumlah dami nangka dan buah nanas dengan nilai $\mathrm{pH}$ selai lembaran yang dihasilkan dapat dilihat pada Gambar 2.

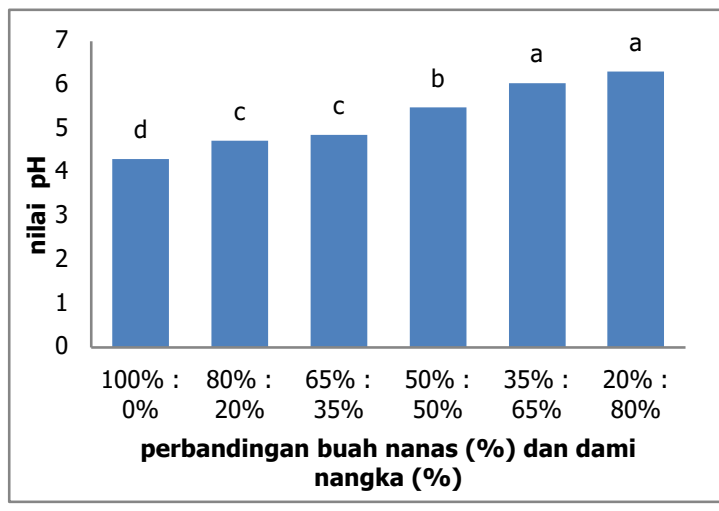

Gambar 2. Pengaruh Perbandingan Jumlah Dami Nangka dan Buah Nanas yang Berbeda Terhadap pH Selai Lembaran

Berdasarkan Gambar 2 menunjukkan bahwa nilai $\mathrm{pH}$ selai lembaran berkisar antara 4,31-6,30. Nilai $\mathrm{pH}$ tertinggi terdapat pada perlakuan P5 (20\% buah nanas : $80 \%$ dami nangka) yaitu 6,30 dan terendah terdapat pada perlakuan P0 (100\% buah nanas). Nilai $\mathrm{pH}$ selai lembaran cenderung semakin meningkat seiring dengan bertambahnya jumlah bubur dami nangka dan berkurangnya jumlah bubur buah nanas. Hal ini diakibatkan karena dami nangka tidak mengandung asam sehingga ketika ditambahkan dalam selai lembaran nilai pHnya menjadi meningkat dan mendekati netral (Wahyuni, 2017). Berdasarkan hasil analisa bahan baku yang dilakukan oleh Wahyuni (2017) pada selai dami nangka dan buah sirsak, dami nangka memiliki pH 5,71. Sehingga nilai pH semakin meningkat seiring dengan semakin banyaknya penambahan bubur dami nangka dan semakin rendah seiring dengan semakin banyaknya penambahan jumlah bubur buah nanas.

\section{Total Padatan Terlarut}

Perbandingan jumlah dami nangka dan buah nanas yang berbeda memberikan pengaruh yang berbeda nyata terhadap kadar

air selai lembaran. Hubungan antara perbandingan jumlah dami nangka dan buah nanas dengan total padatan terlarut (TPT) selai lembaran yang dihasilkan dapat dilihat pada Gambar 3.

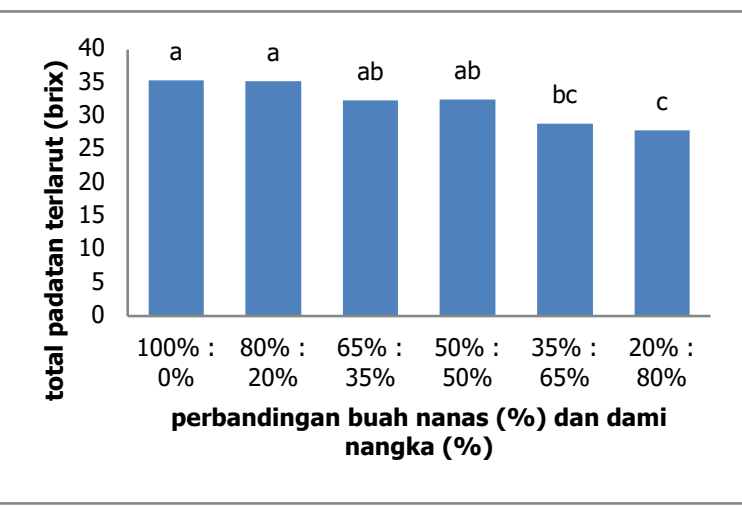

Gambar 3. Pengaruh Perbandingan Jumlah Dami Nangka dan Buah Nanas yang Berbeda Terhadap Total Padatan Terlarut Selai Lembaran

Berdasarkan Gambar 3 menunjukkan bahwa, total padatan terlarut selai lembaran berkisar antara 27,87-35,40 Brix. Total padatan terlarut tertinggi dimiliki oleh perlakuan $\mathrm{P} 1$ (100\% buah nanas) yaitu $35,40^{\circ}$ Brix dan terendah dimiliki oleh perlakuan P5 (20\% buah nanas : $80 \%$ dami nangka) yaitu $27,87^{\circ}$ Brix. Total padatan terlarut pada selai lembaran dari campuran dami nangka dan buah nanas ini cenderung menurun seiring dengan meningkatkan jumlah bubur dami nangka dan menurunnya jumlah bubur buah nanas. Hal ini, sesuai dengan hasil penelitian Wahyuni (2017) yang menyatakan bahwa penambahan dami nangka mengakibatkan total padatan terlarut pada selai campuran dami nangka dan buah sirsak menjadi menurun. Hasil penelitian ini pula didukung dengan hasil penelitian oleh Saputro (2018) yang menyatakan bahwa penambahan buah nanas mengakibatkan meningkatnya total padatan terlarut pada selai dari campuran buah nanas dan sawi. Sehingga total padatan terlarut semakin sedikit seiring dengan semakin banyak penambahan bubur dami nangka dan semakin meningkat seiring dengan semakin banyak penambahan bubur buah nanas.

\section{Tekstur}


Versi Online:

http://www.profood.unram.ac.id/index.php/profood e-ISSN: 2443-3446

Perbandingan jumlah dami nangka dan buah nanas memberikan pengaruh yang tidak berbeda nyata terhadap tesktur selai lembaran. Hubungan perbedaan jumlah dami nangka dan buah nanas dengan tesktur selai lembaran dapat dilihat pada Gambar 4.

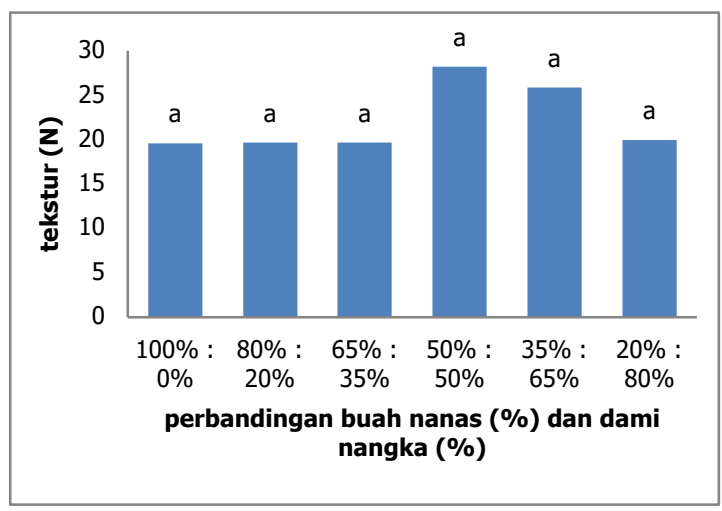

Gambar 4. Pengaruh Perbandingan Jumlah Dami Nangka dan Buah Nanas yang Berbeda Terhadap Tekstur Selai Lembaran

Berdasarkan Gambar 4 menunjukkan bahwa tekstur selai lembaran berkisar antara $19,6-28,2 \mathrm{~g} / \mathrm{mm}^{2}$. Perbedaan perbandingan jumlah dami nangka dan buah nanas yang tidak memberikan pengaruh yang berbeda nyata terhadap tekstur selai lembaran. Hasil ini diduga bahwa tekstur gel dipengaruhi oleh penambahan pengental, dalam penelitian ini pengental yang digunakan adalah tepung agar. Tepung agar yang ditambahkan pada selai lembaran adalah sebesar $0,9 \%$ dari jumlah jumlah bahan baku yaitu dami nangka dan buah nanas. Penambahan jumlah tepung agar sebesar 0,9\% merupakan hasil terbaik dari penelitian Ramadhan (2017) mengenai formulasi selai lembaran. Sehingga penambahan jumlah tepung agar yang sama mengakibatkan tekstur selai lembaran yang dihasilkan tidak berbeda nyata.

\section{Warna}

Perbandingan jumlah dami nangka dan buah nanas memberikan pengaruh yang berbeda nyata terhadap kecerahan dan ${ }^{\circ} \mathrm{Hue}$ selai lembaran. Hubungan perbedaan jumlah dami nangka dan buah nanas dengan kecerahan dan ${ }^{\circ}$ Hue selai lembaran yang dihasilkan pada Gambar 5 dan 6.

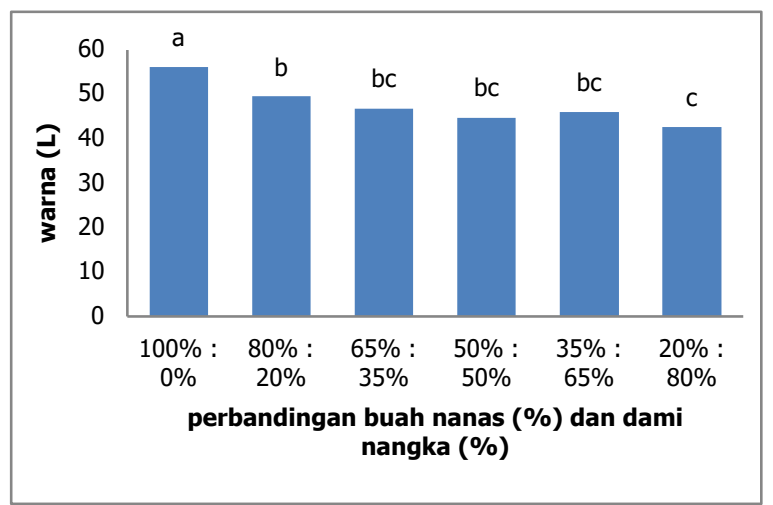

Gambar 5. Pengaruh Perbandingan Jumlah Dami Nangka dan Buah Nanas yang Berbeda Terhadap Kecerahan Selai Lembaran

Berdasarkan Gambar 5 menunjukkan bahwa kecerahan selai lembaran berkisar antara 42,7356,10 dengan kecerahan tertinggi terdapat pada perlakuan P0 (100\% buah nanas) dan kecerahan terendah terdapat pada perlakuan P5 (20\% buah nanas : $80 \%$ dami nangka). Nilai $\mathrm{L}$ pada chromameter menunjukkan tingkat kecerahan dari 0 dengan kriteria hitam sampai 100 dengan kriteria putih.

Kecerahan selai lembaran cenderung berkurang seiring dengan bertambahnya jumlah bubur dami nangka yang ditambahkan dan berkurangnya jumlah bubur buah nanas. Hal ini diakibatkan karena dami nangka memiliki warna keabuan dan cenderung gelap, sehingga ketika ditambahkan warna selai lembaran menjadi lebih gelap. Dami nangka yang dipilih sebagai bahan baku selai lembaran adalah dami nangka yang berwarna putih sehingga bubur dami nangka yang dihasilkan menjadi berwarna keabuan setelah diblansir dan dihancurkan. Menurut Yuwono (2015), dami nangka mengandung gula reduksi sebesar $10,97 \%$. Adanya gula reduksi ini dapat memicu terjadinya reaksi Maillard sehingga selai yang dihasilkan menjadi semakin gelap (coklat). Berdasarkan hasil pengamatan yang dapat dilihat pada gambar 4.5.1, perlakuan PO memiliki kecerahan tertinggi karena pada perlakuan ini tidak ditambahkan dami nangka, sedangkan kecerahan yang paling rendah adalah perlakuan P5 karena pada perlakuan ini dami 
Versi Online:

http://www.profood.unram.ac.id/index.php/profood e-ISSN: 2443-3446

nangka ditambahkan paling banyak daripada perlakuan lainnya. Oleh karena itu kecerahan selai lembaran semakin meningkat seiring dengan semakin banyaknya penambahan bubur buah nanas dan semakin rendah dengan semakin banyaknya penambahan bubur dami nangka.

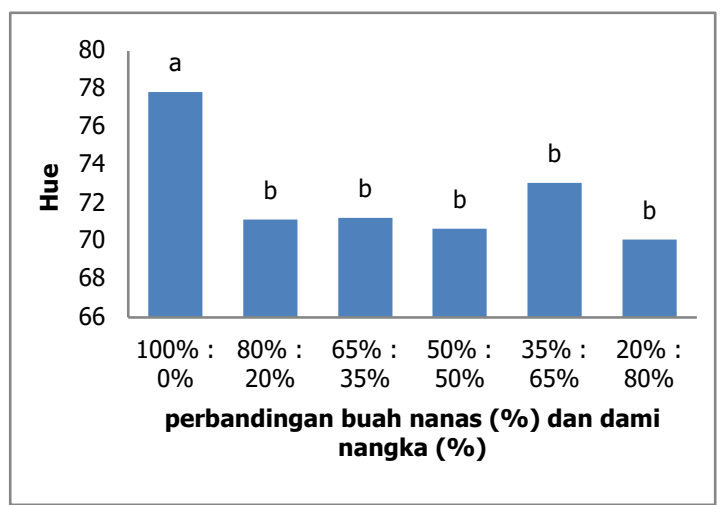

Gambar 6. Pengaruh Perbandingan Jumlah Dami Nangka dan Buah Nanas yang Berbeda Terhadap ${ }^{\circ}$ Hue Selai Lembaran

Berdasarkan Gambar 6 menunjukkan bahwa Hue selai lembaran berkisar antara $70,08^{\circ}-77,84^{\circ}$ dengan Hue tertinggi terdapat pada perlakuan PO (100\% buah nanas) dan Hue terendah terdapat pada perlakuan P5 (20\% buah nanas : $80 \%$ dami nangka). Hue merupakan besaran yang menunjukkan posisi warna suatu objek ke dalam diagram warna Lab. Nilai Hue diperoleh dengan menghitung invers tangen perbandingan $b$ dan a sehingga didapatkan sudut dari diagram warna. Nilai a positif menunjukkan kecenderungan warna merah dan nilai a negatif menunjukkan kecenderungan warna hijau. Nilai $b$ positif menunjukkan kecenderungan warna kuning dan $b$ negatif menunjukkan kecenderungan warna biru. Nilai Hue dinyatakan dalam suatu derajat hue ('Hue) dimana pada setiap derajat tertentu menyatakan warna visual yang dilihat (Hutching, 1999 dalam Safitri, 2009). Nilai hue tersebut kemudian diubah ke dalam kisaran warna hue yang merupakan kisaran warna yang mendekati warna sebenarnya (lampiran 16). Dari analisis yang diperoleh nilai hue selai lembaran berada dalam kisaran warna Yellow-Red (YR).
Meskipun hasil analisis keragaman dan uji lanjut menyatakan bahwa nilai hue berbeda nyata, namun kisaran warna pada rentang ${ }^{\circ} \mathrm{Hue} 54^{\circ}-90^{\circ}$ berada pada daerah kisaran warna Yellow-Red sehingga semua perlakuan memiliki daerah kisaran warna yang sama yaitu Yellow-Red.

\section{Organoleptik Rasa}

Perbedaan perbandingan jumlah buah nanas dan dami nangka memberikan perngaruh yang berbeda nyata terhadap rasa selai lembaran secara skoring dan tidak memberikan pengaruh yang nyata secara hedonik. Hubungan antara perbedaan perbandingan jumlah buah nanas dan dami nangka terhadap rasa selai lembaran baik secara skoring dan secara hedonik dapat dilihat pada Gambar 7 dan 8.

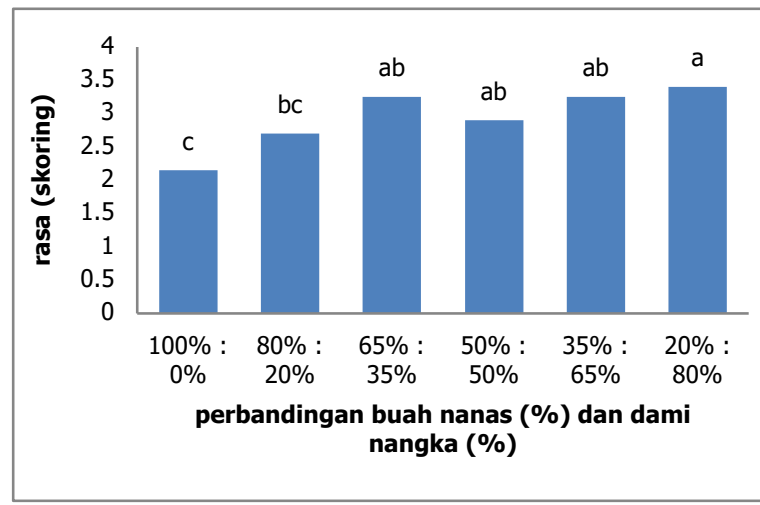

Gambar 7. Pengaruh Perbedaan Perbandingan Jumlah Buah Nanas dan Dami Nangka Terhadap Rasa Selai Lembaran secara Skoring

Berdasarkan Gambar 7 menunjukkan bahwa perbedaan perbandingan jumlah dami nangka dan buah nanas memberikan fasa pengaruh yang berbeda nyata terhadap rasa selai lembaran secara skoring. Berdasarkan tingkat penilaian (skoring) rata-rata panelis memberikan nilai rasa 2,15- 3,40 (berasa asam nanas sampai agak berasa asam nanas) dengan nilai tertinggi pada perlakuan P5 (20\% buah nanas : $80 \%$ dami nangka) sebesar 3,40 dengan kriteria agak berasa asam nanas karena jumlah dami nangka yang ditambahkan lebih banyak dibandingkan dengan perlakuan lainnya mengakibatkan rasa asam dari nanas pada selai lembaran menjadi berkurang dan nilai terendah terdapat pada perlakuan PO (100\% buah nanas) 
Versi Online:

http://www.profood.unram.ac.id/index.php/profood e-ISSN: 2443-3446

sebesar 2,15 dengan kriteria berasa asam nanas. Penambahan dami nangka mengakibatkan rasa asam nanas pada selai lembaran menjadi berkurang. Hal ini disebabkan karena, dami nangka tidak mengandung asam sehingga tidak memiliki rasa yang khas (Wahyuni, 2017).

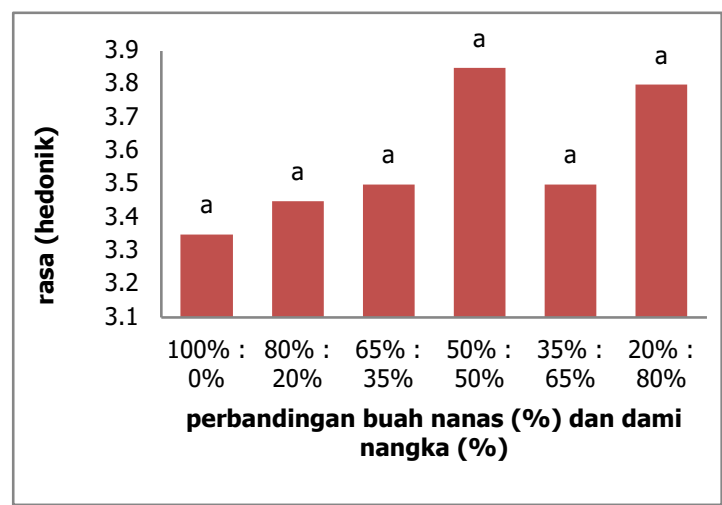

Gambar 8. Pengaruh Perbedaan Perbandingan Jumlah Buah Nanas dan Dami Nangka Terhadap Rasa Selai Lembaran secara Hedonik

Berdasarkan Gambar 8 menunjukkan bahwa perbedaan perbandingan jumlah dami nangka dan buah nanas yang berbeda memberikan pengaruh yang tidak berbeda nyata terhadap rasa selai lembaran pada tingkat kesukaan (hedonik). Rata-rata panelis memberikan penilaian rasa selai lembaran sebesar 3,35-3,85 (agak suka) dengan tingkat kesukaan tertinggi panelis terdapat pada perlakuan P4 (35\% buah nanas : 63\% dami nangka) yaitu sebesar 3,85 dan terendah terdapat pada perlakuan PO $(100 \%$ buah nanas) yaitu sebesar 3,35 sehingga tingkat kesukaan panelis tertinggi terhadap rasa selai lembaran berada pada kriteria agak suka. Hal ini berarti bahwa rasa selai lembaran dengan perbedaan perbandingan jumlah dami nangka dan buah nanas yang berbeda tetap disukai oleh panelis. Hasil penelitian ini tidak sesuai dengan penelitian oleh Wahyuni dkk (2017), dimana perbedaan jumlah dami nangka dan buah sirsak yang berbeda memberikan pengaruh yang berbeda nyata terhadap rasa selai dengan tingkat kesukaan tertinggi terdapat pada perlakuan $20 \%$ dami nangka dan $80 \%$ buah sirsak.

\section{Organoleptik Warna}

Perbedaan perbandingan jumlah buah nanas dan dami nangka memberikan perngaruh yang berbeda nyata terhadap warna selai lembaran secara skoring dan memberikan pengaruh yang tidak berbeda nyata secara hedonik. Hubungan antara perbedaan perbandingan jumlah buah nanas dan dami nangka terhadap warna selai lembaran baik secara skoring dan secara hedonik dapat dilihat pada Gambar 9 dan 10.

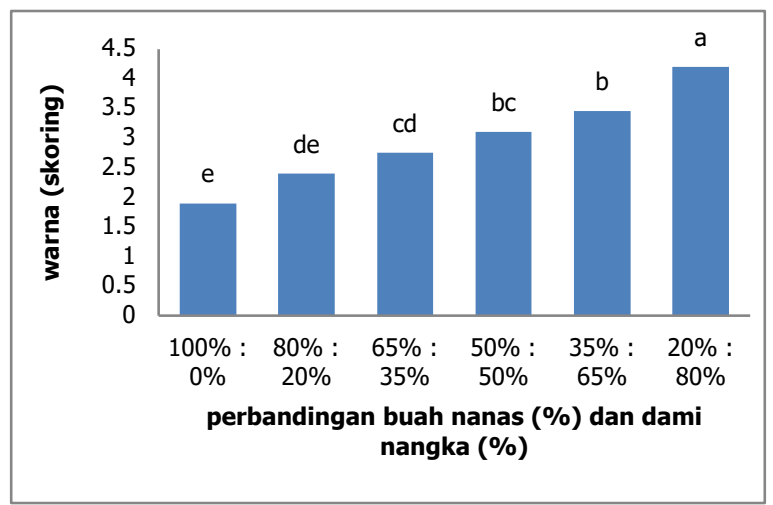

Gambar 9. Pengaruh Perbedaan Perbandingan Jumlah Buah Nanas dan Dami Nangka Terhadap Warna Selai Lembaran secara Skoring

Berdasarkan Gambar 9 menunjukkan bahwa perbedaan perbandingan jumlah dami nangka dan buah nanas memberikan warna selai lembaran yang berbeda nyata secara skoring. Berdasarkan tingkat penilaian (skoring) rata-rata panelis memberikan nilai warna 1,9-4,2 (kuning sampai coklat) dengan nilai tertinggi sebesar 4,2 yaitu pada perlakuan P5 (20\% buah nanas : $80 \%$ dami nangka) dengan kriteria warna coklat muda karena jumlah dami nangka yang ditambahkan lebih banyak dibandingkan dengan perlakuan lainnya sehingga membuat warna selai lembaran menjadi lebih gelap dan nilai terendah sebesar 1,9 pada perlakuan P0 (100\% buah nanas) dengan kriteria warna kuning karena pada perlakuan ini tidak ditambahkan dami nangka. Semakin banyak penambahan dami nangka pada selai lembaran mengakibatkan warna selai lembaran menjadi lebih gelap dengan perlakuan penambahan dami nangka 
terbanyak menghasilkan warna selai lembaran yang paling gelap.

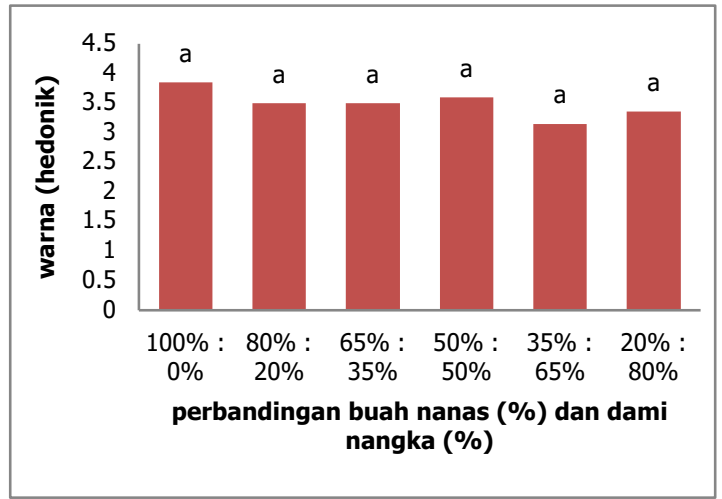

Gambar 10. Pengaruh Perbedaan

Perbandingan Jumlah Buah Nanas dan Dami Nangka Terhadap Warna Selai Lembaran secara Hedonik

Berdasarkan gambar 10 menunjukkan bahwa perbedaan perbandingan jumlah dami nangka dan buah nanas memberikan pengaruh yang tidak berbeda nyata terhadap tingkat kesukaan (hedonik). Rata-rata panelis memberikan nilai warna selai lembaran terhadap tingkat kesukaan berkisar antara 3,15-3,85 (agak suka) dengan tingkat kesukaan panelis tertinggi terdapat pada perlakuan PO (100\% buah nanas) yaitu sebesar 3,85 dan terendah terdapat pada perlakuan P4 (35\% buah nanas : $63 \%$ dami nangka) sebesar 3,15 sehingga tingkat kesukaan panelis tertinggi terhadap warna selai lembaran berada pada kriteria agak suka. Hal ini berarti bahwa warna selai lembaran dengan perbedaan perbandingan jumlah dami nangka dan buah nanas yang berbeda tetap disukai oleh panelis. Hasil penelitian ini tidak sesuai dengan penelitian oleh Wahyuni dkk (2017), dimana perbedaan jumlah dami nangka dan buah sirsak yang berbeda memberikan pengaruh yang berbeda nyata terhadap warna selai secara hedonik dengan tingkat kesukaan terhadap warna yang tertinggi terdapat pada perlakuan $50 \%$ dami nangka dan $50 \%$ buah sirsak.

\section{Organoleptik Tekstur}

Perbedaan perbandingan jumlah dami nangka dan buah nanas terhadap tekstur selai lembaran memberikan pengaruh yang berbeda nyata secara skoring dan memberikan pengaruh yang tidak berbeda nyata secara hedonik. Hubungan antara perbedaan perbandingan jumlah dami nangka dan buah nanas terhadap tekstur selai lembaran baik secara skoring setelah dilakukan uji lanjut menggunakan uji Beda Nyata Terkecil (BNT) pada taraf 5\% dan secara hedonik dapat dilihat pada Gambar 11 dan 12.

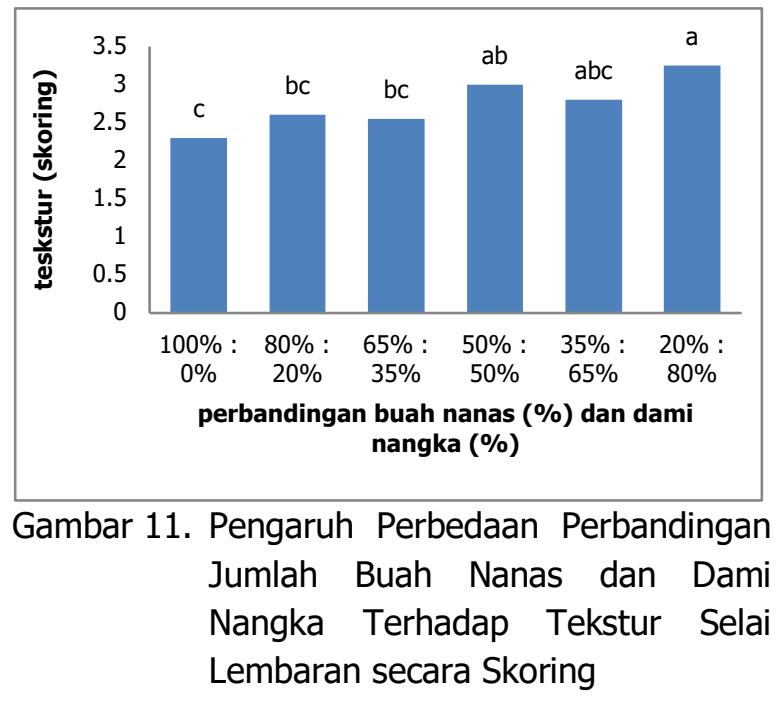

Berdasarkan Gambar 11 menunjukkan bahwa perbedaan perbandingan jumlah dami nangka dan buah nanas memberikan pengaruh yang berbeda nyata terhadap tekstur secara skoring. Berdasarkan tingkat penilaian (skoring) rata-rata panelis memberikan nilai tekstur 2,33,35 (agak kenyal sampai kenyal) dengan nilai tertinggi pada perlakuan P5 (20\% buah nanas : $80 \%$ dami nangka) dengan kriteria kenyal dan nilai terendah pada perlakuan PO $(100 \%$ buah nanas) dengan kriteria agak kenyal. Hasil pengamatan pada uji skoring dan pengujian menggunakan alat penetrometer menunjukkan hasil yang berbeda. Pada pengujian menggunakan alat, hasil pengamatan menunjukkan bahwa tekstur selai lembaran tidak berbeda nyata, sedangkan pada uji skoring menunjukkan bahwa tekstur selai lembaran berbeda nyata. Hal ini dapat terjadi karena pada saat pengujian tidak disediakan selai lembaran komersil sehingga tidak ada pembanding yang jelas untuk selai lembaran yang diuji oleh karena itu panelis belum mampu memberikan penilaian 
yang spesifik terhadap tekstur selai lembaran yang masih dianggap sebagai produk baru.

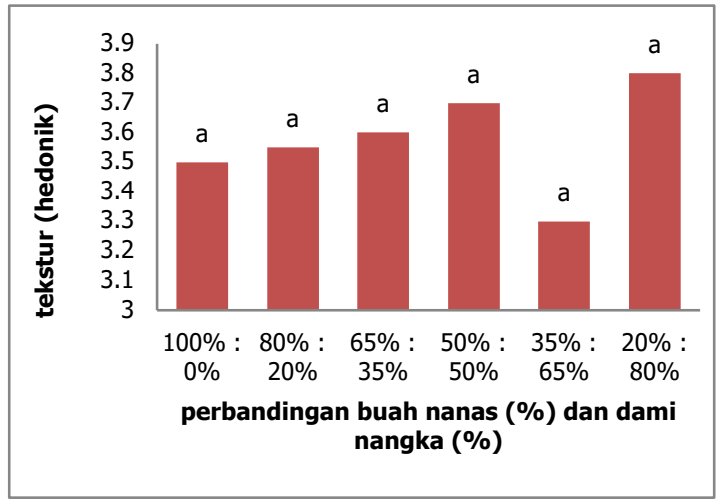

Gambar 12. Pengaruh Perbedaan

Perbandingan Jumlah Buah Nanas dan Dami Nangka Terhadap Tekstur Selai Lembaran secara Hedonik

Berdasarkan Gambar 12 perbedaan perbandingan jumlah dami nangka dan buah nanas memberikan pengaruh yang tidak berbeda nyata terhadap tekstur selai lembaran pada tingkat kesukaan (hedonik). Rata-rata panelis memberikan penilaian tekstur selai lembaran sebesar 3,3-3,8 (agak suka) dengan tingkat kesukaan tertinggi terdapat pada perlakuan P5 (20\% buah nanas : $80 \%$ dami nangka) sebesar 3,8 dan terendah terdapat pada perlakuan P4 (35\% buah nanas : $65 \%$ dami nangka) sebesar 3,3 sehingga tingkat kesukaan panelis tertinggi terhadap tekstur selai lembaran berada pada kriteria agak suka. Hal ini berarti bahwa tekstur selai lembaran dengan perbedaan perbandingan jumlah dami nangka dan buah nanas yang berbeda tetap disukai oleh panelis. Hasil penelitian ini tidak sesuai dengan penelitian oleh Tarmizi (2011), dimana perbedaan jumlah dami nangka dan buah nangka yang berbeda memberikan pengaruh yang berbeda nyata terhadap tesktur selai secara hedonik dengan tingkat kesukaan terhadap tekstur tertinggi terdapat pada perlakuan $65 \%$ dami nangka dan $35 \%$ buah nangka.

\section{Organoleptik Aroma}

Perbedaan perbandingan jumlah buah nanas dan dami nangka memberikan pengaruh yang berbeda nyata terhadap aroma selai lembaran secara skoring dan memberikan pengaruh yang tidak berbeda nyata secara hedonik. Hubungan antara perbedaan perbandingan jumlah buah nanas dan dami nangka terhadap tesktur selai lembaran baik secara skoring setelah dilakukan uji lanjut menggunakan uji Beda Nyata Terkecil pada taraf $5 \%$ dan secara hedonik dapat dilihat pada Gambar 13 dan 14.

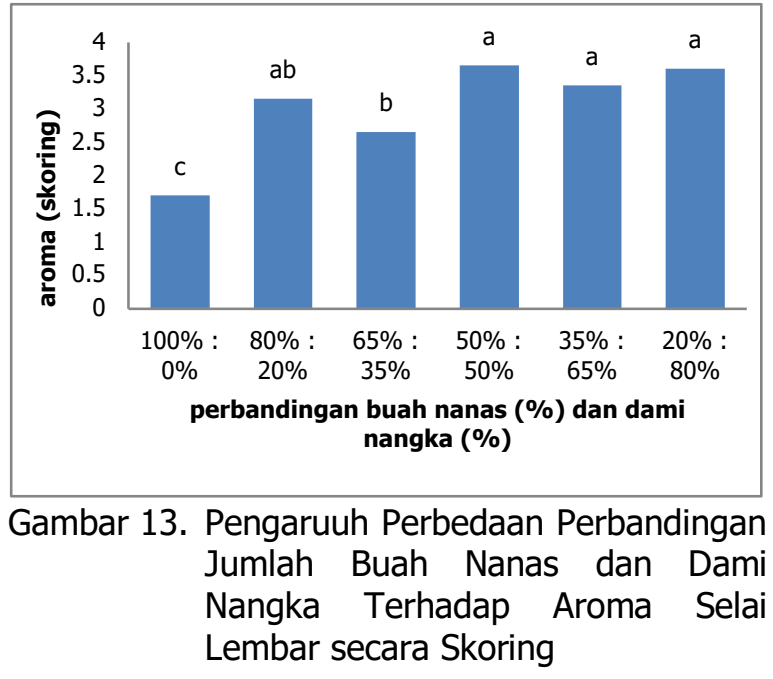

Berdasarkan Gambar 13 menunjukkan bahwa perbedaan perbandingan jumlah dami nangka dan buah nanas memberikan aroma selai lembaran yang berbeda nyata secara skoring. Berdasarkan tingkat penilaian (skoring) rata-rata panelis memberikan nilai 1,7- 3,6 (beraroma nanas sampai beraroma nanas dan beraroma nangka) dengan nilai tertinggi sebesar 3,6 yaitu pada perlakuan P5 (20\% buah nanas : $80 \%$ dami nangka) dengan kriteria beraroma nanas dan nangka karena jumlah dami nangka yang ditambahkan lebih banyak dibandingkan dengan perlakuan lainnya sehingga membuat aroma selai lembaran menjadi campuran aroma nanas dan nangka dan nilai terendah sebesar 1,7 pada perlakuan PO (100\% buah nanas) dengan kriteria beraroma nanas karena pada perlakuan ini tidak ditambahkan dami nangka sehingga aroma selai lembaran hanya beraroma nanas. Penambahan dami nangka yang semakin tinggi mengakibatkan aroma selai lembaran menjadi lebih beraroma nangka. Hal ini dikarenakan dami nangka yang digunakan pada penelitian ini menggunakan nangka jenis nangka salak dengan aroma nangka 
Versi Online:

http://www.profood.unram.ac.id/index.php/profood e-ISSN: 2443-3446

yang sangat kuat meskipun dami nangka tidak memiliki rasa.

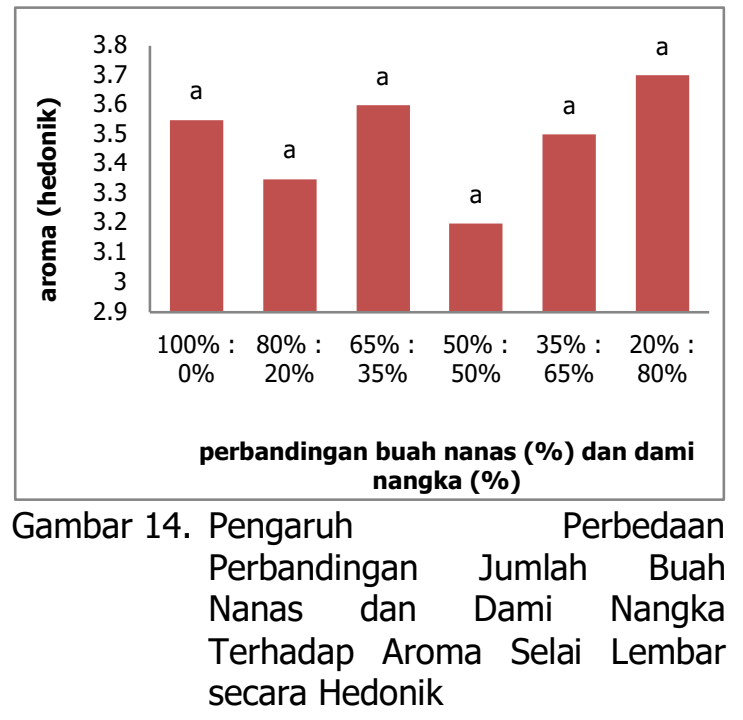

Berdasarkan Gambar 14 menunjukkan bahwa perbedaan perbandingan jumlah dami nangka dan buah nanas memberikan pengaruh yang tidak berbeda nyata pada tingkat kesukaan (hedonik). Rata-rata panelis memberikan nilai warna selai lembaran terhadap tingkat kesukaan berkisar antara 3,35-3,7 (agak suka) dengan tingkat kesukaan panelis tertinggi terdapat pada perlakuan P5 (20\% buah nanas : $80 \%$ dami nangka) yaitu sebesar 3,7 dan terendah terdapat pada perlakuan P2 (80\% buah nanas : $20 \%$ dami nangka) yaitu sebesar 3,5 sehingga tingkat kesukaan panelis tertinggi terhadap aroma selai lembaran berada pada kriteria agak suka. Hal ini berarti bahwa aroma selai lembaran dengan perbedaan perbandingan jumlah dami nangka dan buah nanas yang berbeda tetap disukai oleh panelis. Hasil penelitian ini tidak sesuai dengan penelitian oleh Wahyuni dkk (2017), dimana perbedaan jumlah dami nangka dan buah sirsak yang berbeda memberikan pengaruh yang berbeda nyata dengan tingkat kesukaan terhadap aroma selai secara hedonil dengan tingat kesukaan tertinggi terdapat pada perlakuan $50 \%$ dami nangka dan $50 \%$ buah sirsak.

\section{KESIMPULAN}

Berdasarkan hasil analisa serta uraian pembahasan yang terbatas pada lingkup penelitian ini ditarik kesimpulan sebagai berikut: Perlakuan dengan perbandingan jumlah dami nangka dan buah nanas yang berbeda memberikan pengaruh yang berbeda nyata terhadap kadar air, $\mathrm{pH}$, total padatan terlarut, warna dan organoleptik secara skoring selai lembaran, namun memberikan pengaruh yang tidak berbeda nyata terhadap tekstur gel dan organoleptik secara hedonik selai lembaran. Semakin tinggi jumlah dami nangka yang ditambahkan maka kadar air dan $\mathrm{pH}$ selai lembaran akan meningkat, namun akan menurunkan total padatan terlarut dan kecerahan selai lembaran.

Perlakuan dengan perbandingan $50 \%$ dami nangka dan $50 \%$ buah nanas merupakan perlakuan yang paling disukai panelis pada parameter warna, rasa, dan tekstur dengan karakteristik kadar air 23,35\%, pH 4,86, total padatan terlarut $32,46^{\circ}$ Brix, nilai L 44,79 dan nilai Hue $70,67^{\circ}$ serta dengan sensori warna kuning kecokelatan, agak berasa asam nanas, dengan tekstur kenyal dan beraroma nanas dan sedikit beraroma nangka.

\section{DAFTAR PUSTAKA}

Direktorat Gizi Departemen Kesehatan RI. 1998. Daftar Komposisi Bahan Makanan. Bhratara. Jakarta.

Fachruddin, L., 2008. Membuat Aneka Selai. Kanisius. Yogyakarta.

Handayani, N., 2016. Pemanfaatan Limbah Nangka Sebagai Penganekaragaman Makanan. Jurnal Warta Edisi: 47.

Iswara, D., 2017. Pengaruh Proporsi Apel Anna dan Bunga Rosella Terhadap Sifat Fisikokimia dan Organoleptik Selai Lembaran Apel-Anna-Rosella. Skripsi. Fakultas Teknologi Pertanian. Universitas Katolik Widya Mandala Surabaya.

Ramadhan, W., 2011. Pemanfaatan Agar-agar Tepung Sebagai Texturizer Pada Formulasi Selai Jambu Biji Merah (Psidium guajava L.) Lembaran dan Pendugaan Umur Simpannya. Skripsi. Fakultas Perikanan dan Ilmu Kelautan. IPB, Bogor. 
Versi Online:

http://www.profood.unram.ac.id/index.php/profood e-ISSN: 2443-3446

Ramadhan, W. dan W. Trilaksani, 2017. Formulasi Hidrokoloid-Agar, Sukrosa dan Acidulant pada Pengembangan Produk Selai Lembaran. Jurnal Pengolahan Hasil Perikanan Indonesia. 20 (1): 95-108.

Rayl, J., 2018. Pengaruh Perbandingan Sari Ubi Jalar Ungu (Ipomoea batatas var. Ayamurakasi) dan Sari Dami Nangka (Artocarpus heterophyllus) terhadap Karakteristik Mutu Sirup Dami Nangka. Dhiploma thesis. Fakultas Teknologi Hasil Pertanian. Universitas Andalas.

Standar Nasional Indonesia. 2008. SNI 013746-2008: Selai Buah. Badan Standardisasi Nasional [BSN], Jakarta

Widianto, Sonny. 2009. Kimia Analitik: Gravimetri. Diakses 31 Mei 2014. < http://staff.unila.ac.id/ sonnywidiartofiles/201109/GRAVIMETRI .pdf.>
Pro Food (Jurnal Ilmu dan Teknologi Pangan)

Vol 6 No. 2 November 2020

ISSN: 2443-1095

Standar Industri Indonesia, 1978. Syarat Mutu Selai Buah Nomor 173.

Tarmizi, 2011. Pengaruh Tingkat Pencampuran Daging Buah dengan Dami Nangka Terhadap Mutu Selai Lembaran Nangka (Artocarpus heterophillus) yang Dihasilkan. Skripsi. Fakultas Teknologi Pertania. Universitas Andalas. Padang.

Wahyuni, S., V. S. Johan dan N. Harun, 2017. Pembuatan Selai Campuran Dami Nangka dan Sirsak. JOM FAPERTA. 4 (2) : 1- 15.

Yusmita, L. dan R. Wijayanti, 2018 Pengaruh Penambahan Jerami Nangka (Artocarpus heterophyllus Lam) terhadap Karakteristik Fruit Leather mangga (Mangifera indica L). Jurnal Teknologi dan Industri Pertanian Indonesia. 10 (1): 36-37.

Yuwono, S.S., 2015. Jerami Nangka. http://darsatop.lecture.ub.ac.id/2015/10/3 87/. Diakses pada 25 Agustus 2020) 